\title{
POLITICAL ASPECTS OF NUCLEAR ENERGY MARKET DEVELOPMENT IN THE COUNTRIES OF SOUTH ASIA. NSG FACTOR IN PROMOTING NUCLEAR ENERGY IN THE REGION
}

\author{
Aleksandr Aleksandrovich Boyko \\ Postgraduate Student, Department of World Political Processes, \\ Moscow State Institute of International Relations, Ministry of Foreign Affairs of the Russian Federation \\ alexiurs@gmail.com \\ Prosp. Vernadskogo, 76, 119454 Moscow, Russian Federation
}

\begin{abstract}
South Asian geopolitical face-off of Delhi and Islamabad revealed breaches of the nuclear nonproliferation. This encouraged the greatest nuclear powers to create a mechanism for additional regulation of the nuclear technology and materials export, which is now known as "Nuclear Suppliers' Group". This mechanism aims to impose restrictions for the nuclear technology and materials export to the countries that are not members of NPT. These are nuclear programs of India and Pakistan that are pressing challenge on the agenda.

India has been a very attractive market for nuclear suppliers, especially the United States, so the restrictions were lifted from Delhi in 2008. However, they remained valid for Pakistan, which wasn't an appealing market for the American nuclear exporters. As a result, China, which has been a member of NSG since 2004, has initiated building new NPPs in Pakistan getting mixed reaction of the international community. Despite the clearly contradicting Guidelines, the members of NSG haven't reached common ground on how to restore its supporting role in maintaining the non-proliferation regime. Thus, the Asian nuclear market develops mostly spontaneously, and its future is shaped primarily by the international relations between importers and exporters. Russia isn't able to influence all the NSG members to change the position, however it can take advantage of the situation for developing nuclear cooperation with the Asian countries to support sustainable development of the South Asian energy market.

Key words: Nuclear suppliers' Group, nuclear power, Non-Proliferation Treaty, South Asia, Pakistan, China, India.
\end{abstract}

УДК $327.5(57)$

Дата поступления статьи: 29.01.2016

ББК 66.4(57.32)

\section{ПОЛИТИЧЕСКИЕ АСПЕКТЫ РАЗВИТИЯ АТОМНОГО ЭНЕРГЕТИЧЕСКОГО РЫНКА В СТРАНАХ ЮЖНОЙ АЗИИ. ФАКТОР ГЯП В ВОПРОСАХ ПРОДВИЖЕНИЯ АТОМНОЙ ЭНЕРГЕТИКИ В РЕГИОНЕ}

\footnotetext{
Александр Александрович Бойко

Аспирант кафедры мировых политически процессов, Московский государственный институт международных отношений (университет) МИД России alexiurs@gmail.com просп. Вернадского, 76, 119454 г. Москва, Российская Федерация

Аннотация. Геополитическое противостояние в Южной Азии между Дели и Исламабадом проявило бреши в режиме нераспространения, что побудило крупнейшие атомные державы создать механизм дополнительного регулирования экспорта ядерных технологий и материалов, который сейчас известен как Группа ядерных поставщиков (далее - ГЯП). Этот механизм призван обеспечивать контроль за поставками ядерных
} 
технологий и материалов в страны, не подписавшие Договор о нераспространении ядерного оружия, и именно ядерные программы Индии и Пакистана являются наиболее актуальными вопросами на повестке дня.

Индия рассматривалась как очень привлекательный рынок для ядерных поставщиков, особенно США, и в 2008 г. ограничения ГЯП с Дели были сняты. Но эти ограничения сохранялись для Пакистана, не представляющего экономического интереса для крупных американских экспортеров в атомной энергетической отрасли. В результате Китай, ставший членом ГЯП в 2004 г., начал активно осуществлять различные проекты по строительству АЭС в Пакистане, вызывающие неоднозначную международную реакцию. Несмотря на то что ситуация, сложившаяся на сегодняшний день, противоречит Руководящим принципам ГЯП, позиция относительно шагов по восстановлению инструментальной роли этой структуры в обеспечении режима нераспространения не выработана. Поэтому азиатский рынок атомной энергетики продолжает развиваться во многом стихийно, и его будущее определяется преимущественно уровнем двусторонних отношений стран-импортеров и стран-поставщиков профильных ресурсов.

В сложившейся ситуации Россия может укрепить свои национальные позиции на азиатском атомном энергетическом рынке и содействовать поддержанию международной стабильности в одном из ключевых регионов мира.

Ключевые слова: Группа ядерных поставщиков, атомная энергетика, Договор о нераспространении ядерного оружия, Южная Азия, Пакистан, Китай, Индия.

Ядерная энергетика является важной сферой международного взаимодействия, которая включает научные, рыночные, технические и военные аспекты. Особую остроту и актуальность проблематике «мирного атома» придают вопросы эксплуатации и строительства АЭС, так как вопросы развития атомной энергетики непременно затрагивают и вопросы нераспространения. Поэтому оно характеризуется не только экономическими и техническими параметрами, но имеет и мирополитическую проекцию.

В частности, такие исследователи, как В.И.Рыбаченков [1], В.И.Сотников [2], А.А. Шилин [3] и др., в том или ином виде затрагивали развитие атомной энергетики и ее связь с вопросами нераспространения в Южной Азии. М. Хиббс [5; 9], Т. Дэлтон [5; 6; 9], М. Крепон [6], Дж. Перкович [5] посвятили проблеме региона и роли ГЯП отдельные работы. Заметную роль в осмыслении профильной проблематики играет российский экспертный дискурс, в котором активно участвует ряд авторитетных экспертов ${ }^{1}$.

Режим ядерного нераспространения находится среди ключевых вопросов международной повестки дня. И при благоприятном развитии отношений между Россией и ее западными партнерами, и в период взаимного охлаждения, как это имеет место сегодня, проблематика нераспространения остается важной областью, в которой поддерживается эффективный уровень сотрудничества. Он регламентирует поведение стран в сфере тех- нологий и оборудования ядерного топливного цикла (далее - ЯТЦ). Основные вопросы регулируются различными многосторонними соглашениями, такими как Договор о нераспространении ядерного оружия (далее - ДНЯО), Договор о всеобъемлющем запрещении ядерных испытаний (ДВЗЯИ), конвенция о физической защите ядерных материалов, договоры о безъядерных зонах и пр., а также организациями, в числе которых МАГАТЭ и Совет Безопасности ООН, и другими механизмами. Одним из таких механизмов является Группа ядерных поставщиков (далее - ГЯП).

ГЯП представляет собой «клуб» ядерных поставщиков. Его члены условились содействовать режиму нераспространения путем отказа от сотрудничества с неблагонадежными странами. Группа ядерных поставщиков формально не является организацией, не имеет устава и секретариата, решения в ней принимаются консенсусом. Этот механизм был создан в 1975 г. после испытания Индией атомного оружия в 1974 г. (операция «Улыбающийся Будда»), когда международному сообществу стало ясно, что один лишь ДНЯО не сможет эффективным образом обеспечивать режим нераспространения.

В 1978 г. были разработаны Руководящие принципы ядерного экспорта, опубликованные в виде Информационного циркуляра MAГATЭ (INFCIR/254), также к ним были приложены официальные письма генеральному директору Агентства, в которых сообщалось, что соответствующие правительства 
будут действовать в соответствии с принятыми принципами. В качестве важного условия в Руководящих принципах предусматривается, что поставщики должны разрешать передачу соответствующих материалов, оборудования и технологий «только при наличии официальных правительственных заверений со стороны получателя, ясно исключающих использование, которое может привести к созданию ядерного взрывного устройства». Включение такого обязательства было необходимо в связи с тем, что Франция и некоторые страны - получатели экспорта еще не были участниками ДНЯО.

После того, как стало известно об иракской ядерной программе, в 1992 г. были согласованы Руководящиепринципы по контролю за экспортом товаров двойного использования, которые также были опубликованы в виде Информационного циркуляра МАГАТЭ в виде второй части INFCIR/254. Этими двумя документами руководствуются члены ГЯП.

Основным механизмом в содействии режиму нераспространения является эмбарго участников на поставку технологий и оборудования ЯТЦ в страны, которые не являются подписантами ДНЯО. На момент создания ее участниками являлись семь государств, среди которых были наиболее продвинутые в сфере технологий ЯТЦ державы ${ }^{2}$. За 40 лет существования количество участников расширилось до 48.

В течение этого периода сфера торговли технологиями и оборудованием ЯТЦ становилась все более глобализированной, появились и приобрели влияние различные неправительственные акторы, возникли принципиально новые угрозы режиму нераспространения, количество участников ядерного рынка увеличилось.

Произошли изменения и в самой ГЯП с ростом числа участников появились разногласия относительно того, как лучше взаимодействовать с неподписантами ДНЯО. Подобные дебаты стали еще острее после снятия ограничений ядерного экспорта с Индии в 2008 г. и последующего начала сотрудничества Китая с Пакистаном при нарушении руководящих принципов ГЯП.

Характерно, что традиционно ядерные программы стран Южной Азии являются наи- более частым предметом дискуссий среди участников Группы. Две обозначившиеся в связи с этим линии по модификации достигнутого ранее консенсуса стали серьезным вызовом для функционирования механизма ГЯП в целом. Однако этот механизм остается, тем не менее, важным индикатором стабильности на мировой арене.

\section{1. Расширение южноазиатского рынка атомной энергетики и вопросы толкования отдельных положений Руководящих принципов ядерного экспорта}

К концу 90-х гг. Россией был взят курс на возрождение экономических и научно-технических связей с Индией, серьезно подорванных после развала Советского Союза. В 1998 г. Россия и Индия заключили соглашение о поставке российского ядерного реактора на индийскую площадку Куданкулам. Эта сделка вызвала противодействие со стороны США и некоторых других членов ГЯП. Страны, которые возражали против российско-индийского сотрудничества, считали, что заключенное соглашение не соответствует Руководящим принципам. Кремль настаивал на том, что данный договор не нарушает положения ГЯП, так как является продолжением соглашения о двустороннем ядерном сотрудничестве, заключенном в 1988 г. - за четыре года до разработки Руководящих принципов по контролю за экспортом товаров двойного использования в 1992 г., которые ограничивали бы такого рода сделки. Поэтому, несмотря на американскую позицию, сотрудничество РФ и Индии по строительству АЭС в рамках соглашения 1998 г. было продолжено.

В начале 2000-х гг. Дели столкнулся с серьезной нехваткой топлива на АЭС «Тарапур». Ситуация угрожала вынужденной остановкой реактора, что привело бы к нарушению регионального энергобаланса и, как следствие, работы многих промышленных предприятий. Поэтому в 2001 г. РФ осуществила поставки ядерного топлива для индийских реакторов в Тарапуре, что снова вызвало дебаты среди участников Группы. Россия обосновывала свой подход, ссылалась на пункт, который позволяет совершать ядерные поставки в исключи- 
тельных случаях, когда они «необходимы для безопасной работы существующих ядерных предприятий» [13]. Однако она все-таки приостановила поставки, поскольку ряд участников ГЯП все же посчитали, что экспорт топлива российским предприятием ТВЭЛ нарушает положения Группы.

Когда в 2006 г. Россия вернулась к вопросу участия в поставках на индийский рынок атомного сырья, со стороны участников ГЯП уже не было существенных возражений. Тем не менее в Группе пока не сформировалось единое мнение о том, что следует понимать под безопасной работой ядерных предприятий. Ряд стран, в том числе РФ, придерживаются позиции, что исключения возможны в тех случаях, когда отказ от поставок топлива может привести к вынужденной остановке реактора. Вопрос по-прежнему открыт, однако именно такая российская позиция утвердилась де-факто в международной практике.

В 2005 г. Вашингтон решил предпринять шаги по достижению геополитического преимущества в азиатском регионе в противовес влиянию Китая, а также в интересах получения доступа к перспективному индийскому рынку оборудования и технологий ЯТЦ [6, p. 2]. США и Индия заявили, что ведут переговоры по соглашению о мирном ядерном сотрудничестве, которое позволило бы снять экспортные ограничения ГЯП с Индии. Пакистан и Израиль, которые не являются участниками ДНЯО, отреагировали на международном уровне просьбой выработать аналогичное соглашение и для них, но РФ, США и Франция выступили против такого расширительного подхода. В 2008 г. экспортные ограничения ГЯП для Индии были упразднены, благодаря чему Дели является сегодня полноценным импортером оборудования и технологий ЯТЦ, но ее положение остается исключением в международной практике.

На фоне переговорного процесса по смягчению требований по линии ГЯП, предъявляемых к Индии, в 2006 г. в прессе появилась информация, что Китай планирует экспорт новых реакторов на пакистанскую АЭС «Чашма». Официальные представители США заявили, о невозможности снятия ограничений ГЯП с Пакистана, что делает его ядерное сотрудничество с Пекином не- возможным. Китай долгое время никак не комментировал эту информацию, вероятно, ожидая окончательных результатов переговоров Индии и США. В начале 2010 г., то есть полтора года спустя после снятия ограничений ГЯП с Индии, со стороны Китая было получено официальное подтверждение о том, что он собирается установить в Пакистане два реактора: «Чашма-3» и «Чашма-4» в северо-восточной провинции Пенджаб. Пекин заявил, что сделка является продолжением соглашений 1991 и 2003 гг. ${ }^{3}$, которые предшествовали его вступлению в ГЯП. В марте 2011 г. планирующиеся объекты «Чашма-3» и «Чашма-4» получили гарантии МАГАТЭ, в процессе обсуждения вопроса предоставления гарантий ни один из членов МАГАТЭ не высказал протеста [11]. Решение МАГАТЭ стало примером легитимизации партнерства в сфере мирного атома ad hoc, поскольку при осуществлении этой сделки Китай не обращался в ГЯП с просьбой частичного или полного снятия ограничений.

Летом 2013 г. стало известно о намерении Китая построить еще два реактора на площадке АЭС «Карачи». 5 июля 2013 г. правительство Пакистана утвердило сооружение новых китайских энергоблоков. 26 ноября того же года началось строительство. Существенной реакции со стороны Группы ядерных поставщиков, как и в прошлый раз, не последовало. В январе 2014 г. поступило сообщение, что Исламабад и Пекин ведут переговоры по вопросу строительства еще трех реакторов на новой площадке в Пенджабе, что также не вызвало международного осуждения. Таким образом, в результате расширения сотрудничества с Китаем атомная энергетика Пакистана находится сегодня в стадии активного роста и в целом успешно избегает препятствий, которые могли бы возникнуть в случае применения механизмов ГЯП без учета практики, сложившейся ранее на индийском направлении.

С самого начала среди участников ГЯП не было определенности в том, каким образом реагировать на намечающуюся китайско-пакистанскую ядерную сделку. С начала 2010 г. США придерживались мнения, что планы установить в Пакистане два реактора не могут быть оформлены как продолжение соглашений 
1991 и 2003 годов [18]. В марте 2011 г. помощник госсекретаря США Роберт Блейк заявил: «Мы ожидаем, что Китай будет придерживаться обязательств, которые он взял на себя при вступлении в Группу ядерных поставщиков в 2004 г., и, в частности, мы считаем, что строительство новых ядерных реакторов, таких как «Чашма-3» и «Чашма-4», не соответствует этим обязательствам... мы отчетливо понимаем, что развитие энергетики Пакистана нуждается в поддержке. Помимо ядерной отрасли, существует много других вариантов оказать помощь Пакистану в этой сфере» [10]. Однако ряд других участников ГЯП признал китайско-пакистанскую сделку продолжением соглашений 1991 и 2003 годов. Во многом это было обусловлено стремлением дистанцироваться от одностороннего подхода США, которые в процессе снятия ограничений ГЯП с Индии оказывали жесткое давление на несогласные с ними страны. Неопределенность ситуации усиливалась еще и тем, что американцы сами не хотели идти на открытую конфронтацию с Китаем и Пакистаном (важным американским союзником в Южной Азии) изза вопросов ядерной энергетики.

Дели, так же как и Вашингтон, официально рассматривает ядерную сделку Китая и Пакистана как нарушение руководящих принципов ГЯП [12], однако, судя по всему, индийская сторона все же относится к сделке с пониманием и воздерживается от излишне резких заявлений по этому поводу. В феврале 2011 г. секретарь Индии по иностранным делам Нирупама Рао заявила, что Индия «не против» сотрудничества Китая и Пакистана, однако «некоторые аспекты этого сотрудничества вызывают истинную обеспокоенность». Она добавила, что поддержка Китаем пакистанских ядерных амбиций - это та сфера, где Индия ожидает «большей транспарентности и приветствует открытую дискуссию» [4].

По мнению индийских аналитиков, ввиду наличия гарантий МАГАТЭ установка нового реактора не приведет к существенному усилению пакистанского ядерного арсенала [7], но мирное ядерное сотрудничество Китая и Пакистана может перерасти в военное. К тому же Дели стоит опасаться серьезных инцидентов на ядерных объектах соседней страны, так как они могут отразиться на отноше- нии общества к «мирному атому» в самой Индии (ранее авария на АЭС «Фукусима» уже приводила к массовым протестам против развития атомной энергетики).

Таким образом, позиции США и Индии в отношении китайско-пакистанского партнерства отличается, с одной стороны, высокой степенью критического настроя и достаточной жесткостью официальных заявлений, но одновременно они характеризуются значительной осторожностью, стремлением избежать прямой конфронтации. Что касается индийского подхода (по крайней мере, на уровне экспертного сообщества), то он указывает и на возможность совместного обсуждения многих вопросов мирного атома как с Китаем, так и с Пакистаном.

Китайско-пакистанскую сделку следует рассматривать в контексте индо-американского ядерного соглашения и сотрудничества Дели и Вашингтона в области вооружений. В 2005 г., когда было анонсировано соглашение между США и Индией, Пакистан начал требовать заключить с ним аналогичный договор, который бы позволил ему наравне с Индией стать полноправным участником ядерного рынка. Однако Пакистану было отказано на многих основаниях, среди которых фигурировали высокая активность террористических организаций в стране и деятельность Абдул Кадыр Хана, который торговал ядерными секретами. Пакистан обосновывал свое желание развития ядерной энергетики потребностью в большем количестве источников энергии и необходимостью сохранить стратегический баланс с Индией и не был удовлетворен реакцией американской стороны.

Исламабад действительно сталкивается с острым энергетическим кризисом. Электроэнергетический дефицит за последние годы вырос устрашающе быстро, диспетчерские службы по всей стране вынуждены регулярно проводить сброс нагрузок (отключение потребителя от электросети с целью избежать аварийных ситуаций), некоторые города получают электроснабжение буквально по часам. Пакистану направляется иностранная помощь для проведения капитального ремонта нескольких электростанций, которые не могут работать на номинальной мощности из-за старости и изношенности оборудования [16]. Од- 
нако постоянные проблемы с бюджетом не позволяют достаточно скоро ввести в строй новые энергетические предприятия, чтобы эффективно устранить дефицит, который не просто не уменьшается, но продолжает расти и уже достигает 8500 МВт [8].

Несмотря на эти объективные реалии, существует и другая сторона вопроса. Стоит заметить, что Исламабад не высказывал настойчивого желания развивать свою энергетику на основе «мирного атома» до индо-американского ядерного соглашения, в связи с чем представляется вероятным, что его позиция существенно мотивировалась реакцией на снятие ограничений ГЯП с Индии. Пакистану, который в отличие от своего индийского соседа не имеет глобальных амбиций и буквально «зациклен» на региональной конкуренции, трудно согласиться с перспективами увеличения экономического отставания от Индии. Пакистанская элита продолжает настаивать на том, чтобы ее рассматривали в качестве не менее значимого регионального игрока, чем индийских соседей.

Кроме того, Пакистан опасается, что Индия в конце концов вступит в ГЯП, о чем идут активные переговоры. Председатель ГЯП Рафаэль Гросси, пребывая с визитом в Нью-Дели, отметил, что у Индии «имеются все необходимые для членства составляющие». Он считает, что «никто из членов ГЯП не будет возражать против <вступления> Индии» [17]. Дели, узаконив де-факто свой ядерный статус, не допустит консенсуса при обсуждении вопроса вступления Исламабада [9; 14] и тем самым навсегда оставит его в числе «ядерных аутсайдеров». Поэтому активное развитие атомной энергетики пакистанской стороной рассматривается как «билет» в «ядерный мейнстрим» через участие в ГЯП и других механизмах ядерного регулирования. Именно по этой причине Пакистан прикладывает все силы, чтобы стать участником ГЯП если не раньше Дели, то хотя бы одновременно с ним.

Интерес Китая в контексте индо-пакистанской конкуренции по поводу ядерной энергетики не вполне очевиден. Пекин выразил явное недовольство американо-индийской сделкой, которая обеспечила снятие ограничений ГЯП с Индии, и Пакистан, скорее все- го, рассматривается китайской стороной в качестве инструмента артикуляции своей позиции. Пекин настаивает на том, что строительство новых энергоблоков на АЭС «Чашма» является продолжением соглашений, которые предшествовали его вступлению в ГЯП ${ }^{3}$. Другие, более новые, проекты КНР никак не обосновывает, полагая, вероятно, что они являются реализацией ранее обозначенных подходов к вопросам пакистанской энергетики.

Тем не менее КНР стремится избежать ухудшения отношений с Дели, поэтому вопросы энергетического сотрудничества Китая и Пакистана практически никак не обсуждаются в рамках китайско-индийского диалога.

Представляется, что развитие ядерной энергетики и решение важнейшей энергетической проблемы для руководства Пакистана является не единственной задачей в настоящее время. Исламабад вкладывает максимум усилий как во внутренней, так и внешней политике для преодоления существенного отставания от Дели в военно-технической и экономической сфере. Китай как могущественная держава стремится сохранить условный паритет Пакистана с Индией, утверждая таким образом свой политический подход к развитию международных процессов.

\section{2. Перспективы урегулирования}

\section{международного статуса пакистанской ядерной энергетики}

Глобальный режим ядерного нераспространения, как и другие международные режимы, демонстрирует значительную зависимость от политической практики. И если его «оружейный сегмент» сохраняет достаточно высокую степень стабильности, то энергетический является более изменчивым, требующим регулярного уточнения правил и рамок взаимодействия различных акторов. Китайский подход позволил мировому сообществу понять, что ГЯП не являются «perpetum mobile» регулирования международного взаимодействия в сфере «мирного атома» и что глобальные установки могу видоизменяться на основе регионального опыта.

Сегодня у Пекина реальные возможности закрепить свою позицию. В течение бли- 


\section{МЕЖДУНАРОДНЫЕ ОТНОШЕНИЯ}

жайших десятилетий КНР способна стать одним из влиятельных ядерных поставщиков мирового уровня, чье участие в ГЯП будет особенно важно для соблюдения режима нераспространения. Очевидно, что другие страны, в том числе США, не готовы пойти на открытую конфронтацию с Пекином. Поэтому, несмотря на то что на пакистанском направлении ГЯП столкнулась с неоднозначной по формальным признакам ситуацией, в нынешних обстоятельствах мировому сообществу остается лишь контролировать китайско-пакистанское сотрудничество через МАГАТЭ.

Устанавливая свои реакторы в Пакистане, Пекин не только приобретает козыри, но и рискует будущим в качестве ядерного поставщика. Любой серьезный инцидент на китайской АЭС повлечет за собой недоверие к китайским ядерным реакторам. Однако Китай за десятилетия развития своей атомной программы зарекомендовал себя в качестве добросовестного, надежного оператора и строителя АЭС.

Атомная энергетика занимает очень важное место в китайской энергетической стратегии, какие-либо серьезные инциденты на атомных объектах в стране крайне нежелательны и могут привести к массовым антиядерным движениям среди населения, что в свою очередь подстегнет антиправительственные настроения в КНР [5, p. 4]. Остается надеяться, что риски, связанные с развитием атомной энергетики Исламабада, просчитаны и в достаточной мере осознаются Пекином.

Развитие атомного энергетического рынка в Южной Азии, главной несущей конструкцией которого пока выступают ресурсы Индии и Пакистана, характеризуется как противоречиями, так и шагами по их преодолению. С точки зрения соблюдения режима нераспространения создание по инициативе США в 2008 г. исключений из принципов ГЯП для Индии было заведомо неудачным решением, особенно принимая во внимание военно-политическое моменты региональной напряженности.

Парадокс заключается в том, что сегодня сотрудничество Китая и Пакистана, также в известном смысле выходящее за рамки правил ГЯП, способствует поддержанию регио- нального ядерного паритета в Южной Азии. Таким образом, расширяется окно возможностей как для предотвращения использования мирного атома в немирных целях, так и для выполнения миссии МАГАТЭ в отношении ядерной энергетики Индии и Пакистана. Кроме того, в среднесрочной перспективе подобный, хотя во многом условный, паритет самым серьезным образом сдерживает инициативы любой из сторон по достижению технологического прорыва в области ядерных вооружений и средств доставки на пространстве Южной Азии.

\section{3. Окно возможностей}

\section{для преодоления противоречий атомного энергетического рынка Южной Азии}

Страны Южной Азии играют большую роль в современной мировой политике. В развитии позитивных отношений между ними, которые во многом зависят от успешного решения энергетических проблем, заинтересовано все мировое сообщество. Но для преодоления противоречий, которые существуют в контексте формирования южноазиатского рынка, ядерной энергетике целесообразно учесть ряд соображений.

Во-первых, Пакистан стремится к получению статуса, аналогичного индийскому, не только в целях не допустить своего отставания в региональной конкуренции, но и как к средству, которое предоставит доступ к более продвинутым реакторам, технологиям ЯТЦ и лицензиям, достижимому посредством сотрудничества с рядом передовых держав, в том числе поставщиками КНР.

ГЯП могли бы сыграть на интересах Пакистана и снять ограничения с Исламабада при выполнении ряда условий и присоединения к некоторым международным соглашениям, таким как Договор о всеобъемлющем запрещении ядерных испытаний и Договор о запрете производства делящихся материалов или каким-либо другим образом, подразумевающим одностороннее ограничение ядерного арсенала со стороны Пакистана. В октябре 2015 г. в ряде ведущих американских и индийских газет появилась информация, что между США и Пакистаном пла- 
нируется ядерная сделка, которая будет существенно отличаться от условий сделки с Индией, предшествующей снятию ограничений ГЯП. Сообщалось, что соглашение должно подразумевать введение ограничений на пакистанский ядерный арсенал. 15 октября 2015 г., отвечая на вопрос журналиста, пресссекретарь Белого дома Джош Эрнест заметил, что осведомлен про сообщения в прессе о ядерной сделке и добавил, что «США и Пакистан регулярно обсуждают в своем диалоге вопросы ядерной безопасности» [15]. Фактически, слова американского пресс-секретаря можно толковать как подтверждение сообщений зарубежных изданий. Однако Исламабад никогда не согласится на одностороннее ограничение своего ядерного вооружения, не говоря уже о подписании ДНЯО, и, следовательно, США не удастся решить вопрос в двустороннем порядке - потребуется более проработанный многосторонний консенсус. Так или иначе, бесконечное продолжение изоляции Пакистана, особенно после снятия ограничений ГЯП с Индии, лишь приведет к усилению его ядерного арсенала и росту напряженности в регионе.

Во-вторых, ГЯП нуждается в реформах. Прежде всего Группа должна стать полноценной организацией, Руководящие принципы необходимо заменить уставом, положения которого должны быть усовершенствованы и лишены многочисленных юридических лазеек. Ввиду увеличения числа участников нынешний принцип консенсуса целесообразнее заменить процедурой голосования и наделить ключевых ядерных игроков, таких как Россия, Китай, США, особыми правами. В ГЯП должна быть предусмотрена процедура наложения определенных санкций и штрафов по отношению к недобросовестным участникам, также следует развернуть (и прописать в уставе) более тесное сотрудничество с Советом безопасности ООН для противодействия нарушителям вне Группы. Однако проведение таких реформ связано со многими сложными вопросами, решение которых требует дополнительного времени.

Тем не менее ситуация, создавшаяся в результате неудачного шага ГЯП в декабре 2008 г., требует решения. Представляется важным найти способ «легализации» ядерного сотрудничества Пакистана с Китаем, ко- торый бы устраивал не только Исламабад, но и Дели. Наиболее разумным шагом в данной ситуации было бы предоставить Пакистану возможность импортировать технологии и оборудование ЯТЦ при условии разделения ядерной инфраструктуры на мирную и военную, подписания двустороннего соглашения с Индией об ограничении производства делящихся материалов и средств доставки. Пакистан должен пересмотреть свою ядерную доктрину и оставить возможность применения ядерного оружия лишь как ответ на агрессию стратегического масштаба. В интересах международного сообщества, в том числе и России, смягчить противостояние Индии с Китаем и Пакистаном, чему способствовал бы подобный шаг. Более того, Москва может извлечь дополнительные преимущества из пересмотра ограничений для энергетики Исламабада. Несмотря на то что Пакистан не представляет коммерческого интереса для Москвы, она может использовать пакистанский прецедент как аргумент в спорных ситуациях, аналогичных той, что возникла при строительстве АЭС «Бушер» в Иране.

В-третьих, легализация пакистано-китайского сотрудничества усилит политическое влияние Китая в регионе и мире. Пакистан может послужить для Пекина площадкой для повышения эффективности строительства, развития опыта эксплуатации и демонстрации надежности его энергоблоков. В далекой перспективе из этого сотрудничества сможет извлечь выгоду и Израиль, который уже более 40 лет стремится осуществить проект строительства АЭС в Негеве.

В условиях обострения отношений с Западом России необходимо дополнительно проанализировать многие вопросы международной повестки дня во всех их деталях. Пакистанокитайская ядерная сделка не несет в себе какой-либо угрозы для России [2]. Москва не в состоянии повлиять на позицию всех партнеров по ГЯП, поэтому необходимо использовать сложившуюся ситуацию для углубления сотрудничества с азиатскими странами в области технологий и оборудования ЯТЦ с тем, чтобы поддержать устойчивое развитие атомного энергетического рынка Южной Азии на взаимовыгодной основе и содействовать обеспечению международной безопасности. 


\section{ПРИМЕЧАНИЯ}

1 Д.В. Баранов, Л.А. Большов, А.В. Губин, Л.Ю. Гусев, К.Б. Комаров, С.В. Кондратьев, Д.В. Кумановский, В.Т. Поцяпун, М.А. Троицкий и др.

${ }^{2}$ Великобритания, Канада, СССР, США, Франция, ФРГ и Япония.

${ }^{3}$ Согласно договору 1991 г. между Китаем и Пакистаном была осуществлена установка первого 325 МВт реактора «Чашма-1»; соглашение 2003 г. предусматривало возможность дальнейшего расширения АЭС «Чашма».

\section{СПИСОК ЛИТЕРАТУРЫ}

1. Рыбаченков, В. И. Нераспространение ядерного оружия и запрет на ядерные испытания. Режим инспекций МАГАТЭ. Лекция в МФТИ. 25.03.2003 / В. И. Рыбаченков. - Электрон. текстовые дан. - Режим доступа: http://www.armscontrol.ru/ course/lectures03a/vir30325a.htm. - Загл. с экрана.

2. Сотников, В. И. К вопросу о пакистано-китайской ядерной сделке. Институт Ближнего Востока. 12.07.2010 / В. И. Сотников - Электрон. текстовые дан. - Режим доступа: http://www.iimes.ru/rus/ stat/2010/12-07-10b.htm. - Загл. с экрана.

3. Шилин, А. А. Ядерные программы Индии и Пакистана. Лекция в МФТИ. 23.03.2006 / А. А. Шилин. - Электрон. текстовые дан. - Режим доступа: http://www.armscontrol.ru/course/lectures06a/ aas060323.pdf. - Загл. с экрана.

4. Be transparent in N-ties with Pak: India to China // DNA. 13.02.2011. - Electronic text data. Mode of access: http://www.dnaindia.com/india/ report-india-seeks-more-transparency-in-chinasnuclear-ties-with-pakistan-1507165. - Title from screen.

5. Dalton, T. A Criteria-Based Approach to Nuclear Cooperation With Pakistan / T. Dalton, M. Hibbs, G. Perkovich // Carnegie Endowment for International Peace. 22.06.2011. - Electronic text data. Mode of access: http://carnegieendowment. org/files/ nsg_criteria.pdf. - Title from screen.

6. Dalton, T. ANormal Nuclear Pakistan/T. Dalton, M. Krepon // Stimson Center and Carnegie Endowment for International Peace. - Electronic text data. - Mode of access: http://carnegieendowment.org/files/Normal NuclearPakistan.pdf. - Title from screen.

7. Don't lose sleep over Chashma // The Hindu. 23.06.2010. - Electronic text data. - Mode of access: http://www.thehindu.com/todays-paper/tp-opinion/ dont-lose-sleep-over-chashma/article481369.ece. - Title from screen.

8. Electricity shortfall in the country reaches 8,500 MW // Dawn. - Electronic text data. - Mode of access: http://www.dawn.com/news/727263/residents-protestprolonged-loadshedding-in-lahore. - Title from screen.

9. Hibbs M. Nuclear Suppliers Group: Don’t Rush New Membership / M. Hibbs, T. Dalton // Carnegie Endowment for International Peace. 14.06.2012. - Electronic text data. - Mode of access: http://carnegieendowment. org/2012/06/14/nuclear-suppliers-group-don-t-rush-newmembership. - Title from screen.

10. Horner, D. Chinese-Pakistani Reactor Deal Moves Ahead / D. Horner // Arms Control Today, April 2011. Electronic text data. - Mode of access: https://www. armscontrol.org/act/2011_04/ChinaPakistan. - Title from screen.

11. INFCIRC/816. 17.05.2011.-Electronic text data. Mode of access: https://www.iaea.org/publications/ documents/infcircs/agreement-between-internationalatomic-energy-agency-and-governmen-0. - Title from screen.

12. Lok Sabha starred question № 2921, Ministry of External Affairs. Government of India. - Electronic text data. - Mode of access: http://www.mea.gov.in/loksabha.htm?dtl/24469/QNO2921 MEMBERSHIP+IN+ NSG. - Title from screen.

13. Paragraph 4 (b) of INFCIRC/254/Rev.2/Part 1, October 1995. - Electronic text data. - Mode of access: https://www.iaea.org/sites/default/files/publications/ documents/infcircs//infcirc254r2p1.pdf. - Title from screen.

14. Perkovich, G. Once India Is Inside NSG, It Would Forever Block Pakistan From Entering It / G. Perkovich.Electronic text data. - Mode of access: https:// www.youtube.com/watch?v=ZqRsj3kYI7A. - Title from screen.

15. Press Briefing by Press Secretary Josh Earnest 15.10.2015 // The White House Office of the Press Secretary. - Electronic text data. - Mode of access: https:/www.whitehouse.gov/the-press-office/2015/ $10 / 15 /$ press-briefing-press-secretary-josh-earnest10152015. - Title from screen.

16. Shabbir, H. Kazmi, Pakistan's Energy Crisis / H. Shabbir // The Diplomat. 13.04.2013. - Electronic text data. - Mode of access: http://thediplomat.com/ 2013/08/pakistans-energy-crisis/. - Title from screen.

17. Suhasini, H. 'Nuclear suppliers may admit India' / H. Suhasini // The Hindu. 31.10.2015. Electronic text data. - Mode of access: http:// www.thehindu.com/news/national/nuclear-suppliersmay-admit-india/article7824763.ece. - Title from screen.

18. Transshipment and Diversion: Are U.S. Trading Partners Doing Enough to Prevent the Spread of Dangerous Technologies? Hearing Before the Subcommittee on Terrorism, Nonproliferation and Trade, Committee on Foreign Affairs, House of Representatives, 111th Congress, 2nd session. 22.07.2010, Serial № 111- 


\section{МЕЖДУНАРОДНЫЕ ОТНОШЕНИЯ}

122. - Electronic text data. - Mode of access: http:// www.gpo.gov/fdsys/pkg/CHRG-111hhrg57609/html/ CHRG-111hhrg57609.htm. - Title from screen.

\section{REFERENCES}

1. Rybachenkov V.I. Nerasprostranenie yadernogo oruzhiya i zapret na yadernye ispytaniya. Rezhim inspektsiy MAGATE [Non-Proliferation and Nuclear Test Ban. IAEA Inspections Mode]. Lecture at MIPHT. March 25, 2003. Available at: http://www. armscontrol.ru/course/lectures03a/vir30325a.htm.

2. Sotnikov V.I. K voprosu o pakistanokitayskoy yadernoy sdelke [Revisiting China-Pak Deal]. Istitute of the Middle East, July 12, 2010. Available at: http://www.iimes.ru/rus/stat/2010/12-0710b.htm.

3. Shilin A.A. Yadernye programmy Indii i Pakistana [Nuclear Programs of India and Pakistan]. Lecture at MIPHT. March 23, 2006. Available at: http:// www.armscontrol.ru/course/lectures06a/aas060323.pdf.

4. Be transparent in N-ties with Pak: India to China. DNA. February 13, 2011. Available at: http:// www.dnaindia.com/india/report-india-seeks-moretransparency-in-chinas-nuclear-ties-with-pakistan1507165.

5. Dalton T., Hibbs M., Perkovich G. A CriteriaBased Approach to Nuclear Cooperation With Pakistan. Carnegie Endowment for International Peace. June 22, 2011. Available at: http://carnegieendowment.org/ files/nsg_criteria.pdf.

6. Dalton T., Krepon M. ANormal Nuclear Pakistan. Stimson Center and Carnegie Endowment for International Peace. Available at: http:// carnegieendowment.org/files/NormalNuclearPakistan.pdf

7. Don't lose sleep over Chashma. The Hindu. June 23, 2010. Available at: http://www.thehindu.com/ todays-paper/tp-opinion/dont-lose-sleep-overchashma/article481369.ece.

8. Electricity shortfall in the country reaches 8,500 MW. Dawn. Available at: http://www.dawn.com/ news/727263/residents-protest-prolonged-loadsheddingin-lahore.
9. Hibbs M., Dalton T. Nuclear Suppliers Group: Don't Rush New Membership. Carnegie Endowment for International Peace. June 14, 2012. Available at: http://carnegieendowment.org/2012/06/14/nuclearsuppliers-group-don-t-rush-new-membership.

10. Horner D. Chinese-Pakistani Reactor Deal Moves Ahead. Arms Control Today, April 2011. Available at: https://www.armscontrol.org/act/ 2011 04/ChinaPakistan.

11. INFCIRC/816, May 17, 2011. Available at: https://www.iaea.org/publications/documents/ infcircs/agreement-between-international-atomicenergy-agency-and-governmen- 0 .

12. Lok Sabha starred question no. 2921, Ministry of External Affairs. Government of India. Available at: http://www.mea.gov.in/lok-sabha.htm?dtl/24469/ QNO2921MEMBERSHIP+IN+NSG.

13. Paragraph 4 (b) of INFCIRC/254/Rev.2/ Part 1, October 1995. Available at: https://www. iaea. org/sites/default/files/publications/documents/ infcircs//infcirc254r2p1.pdf.

14. Perkovich G. Once India Is Inside NSG, It Would Forever Block Pakistan From Entering It. Available at: https://www.youtube.com/watch?v=ZqRsj3kYI7A.

15. Press Briefing by Press Secretary Josh Earnest 15.10.2015. The White House Office of the Press Secretary. Available at: https:/www.whitehouse.gov/ the-press-office/2015/10/15/press-briefing-presssecretary-josh-earnest-10152015.

16. Shabbir H. Kazmi, Pakistan's Energy Crisis. The Diplomat. 13.04.2013. Available at: http:// thediplomat.com/2013/08/pakistans-energy-crisis/

17. Suhasini H. 'Nuclear suppliers may admit India'. The Hindu. October 31, 2015. Available at: http:/ /www.thehindu.com/news/national/nuclear-suppliersmay-admit-india/article7824763.ece.

18. Transshipment and Diversion: Are U.S. Trading Partners Doing Enough to Prevent the Spread of Dangerous Technologies? Hearing Before the Subcommittee on Terrorism, Nonproliferation and Trade, Committee on Foreign Affairs, House of Representatives, 111th Congress, 2nd session. July 22, 2010, Serial No. 111122. Available at: http://www.gpo.gov/fdsys/pkg/CHRG111hhrg57609/html/CHRG-111hhrg57609.htm. 